\title{
Haptolana trichostoma, a new genus and species of troglobitic cirolanid isopod from Cuba
}

By Thomas E. Bowman ${ }^{1}$ )

With plates $24(1)-2 \%(4)$

Of the 7 species of troglobitic cirolanid isopods reported from the Western Hemisphere (summarized in Bowman, 1964), only Troglocirolana cubensis (Hay) is native to Cuba, where it occurs in Habana Province in the western part of the island. An excellent description of T. cubensis is given by Rioja (1957). In 1959, 2 specimens of an undescribed troglobitic cirolanid were collected in a cave in Camagüey Province, in eastern Cuba, by Gilberto Silva Taboada, who kindly donated them to the United States National Museum. I wish to express my gratitude to Mr. Silva for making known this interesting isopod, which is described below.

\section{Haptolana, new genus}

Blind, unpigmented. Lateral margins of pleonite 5 covered by pleonite 4. Antenna 1 with 2 -merous peduncle, 1 st segment expanded. Frontal lamina broad, not carinate, not produced anteriad in middle. Mandibular palp directed posteriad. Pereopods 1-7 prehensile. Pleopods 1-2 undivided, with marginal setae. Pleopods 3-5: exopod with partial transverse suture and marginal setae; endopod undivided, without marginal setae. Gender, feminine. Type-species, Haptolana trichostoma, new species.

The generic name is derived from the Greek "hapto", to grasp, plus (Ciro)lana, and refers to the prehensile nature of all 7 pereopods.

\section{Haptolana trichostoma, new species}

Figures 1-33

Length of holotype $13.8 \mathrm{~mm}$, of paratype $11.6 \mathrm{~mm}$. Body rather stocky, about twice as long as wide. Head round in front, posterolateral corners covered by pereonite 1 . Frontal lamina only slightly longer than wide. Pereonites subequal in length. Coxal plates with

\footnotetext{
1) Smithsonian Institution, Washington, D.C., U.S.A.
} 
low carinae; posteroventral corners becoming progressively more produced in posterior coxae, that of pereonite 7 reaching posterior margin of pleonite 2. Penis lobes short, blunt. Pleonites short and broad; pleonite 5 the longest. Pleonite 1 partly covered by pereonite 7 ; posterolateral margins of pleonites 2-4 angularly produced. Ventral surface of pleonites 1-4 with pointed processes lateral to bases of pleopods; pleonites concave between processes and posterolateral margins. Telson lingulate, slightly wider than long; posterior margin nearly straight, crenulate, with sharp spines between crenulations and 2-3 plumose setae between each pair of spines.

Antenna 1 reaching beyond middle of pereonite 1 . Peduncle 2merous; segment 1 broad, lower margin overlapping 1st 2 segments of antenna 2, upper margin protruding above anterior margin of head, ridge-like in lateral view (fig. 4); segment 2 slender, armed distally as in fig. 11. Flagellum 13-merous, each segment with $2-3$ esthetes on ventral surface, every other segment with 1 to several setae on either side of esthete, apical segment with 3 esthetes and about 10 setae (fig. 13).

Antenna 2 reaching middle of pereonite 4. Peduncle 5-merous, segments 1-2 partly covered by segment 1 of antenna 1. Flagellum 36-merous, segments armed below with 2 groups of 4 setae; segments having 1 or a small group of setae on anterior margin alternate with segments having a seta on upper surface.

Mandibles asymmetrical, left incisor overlapping right; teeth more deeply divided in left incisor than in right; lacinia mobilis present on both mandibles, bearing about 12 marginal spines and numerous surface hairs; molar also with numerous surface hairs and a row of about 22 curved spines; palp directed posteriad, 2nd segment relatively short. Maxilla 1 armed as shown in fig. 17, the 3 endopodal spines unusually robust. Endopod of maxilla 2 with numerous surface hairs. Inner ramus of maxilliped with 4 plumose setae and single coupling spine.

Pereopods all prehensile, with dactyl closing against groove in propod between 2 rows of robust spines. Pereopods 1-3 similar, subequal in length, with very short carpus; anterior margin of merus armed with several blunt spines. Pereopods $4-7$ similar, longer than pereopods 1-3, without blunt spines on merus, but with rows of slender spines on distal margins of ischium, merus, and carpus, and fine hairs along anterior margins of ischium, merus, carpus, and proximal part of propod; carpus nearly as long as merus. "Dactyl organ" near distal end of dactyl on all pereopods, composed of 7 setae. 
Endopod of pleopod 1 about $2 / 3$ as wide as exopod, medial margin straight, bearing close-set row of setules. Stylet of male pleopod 2 inserted near base of endopod, about $1 / 3$ longer than endopod, gradually tapering to slender tip; seen under high magnification tip is divided (fig. 30). Uropod reaching posterior margin of telson; peduncle strongly produced medially, bearing a pair of setae on ventral surface; exopod about $2 / 3$ as wide as endopod, margins of both rami with spines alternating with rows of 2-4 plumose setae and with apical clusters of longer naked setae (fig. 9).

Types: ô holotype, USNM 111478, immature paratype, USNM 111479, collected May 1959 in Cueva Bonita, Sierra de Cubita, Camagüey Province, Cuba, by Gilberto Silva Taboada.

The specific name, "trichostoma", proposed as a noun, is from the Greek "tricho" (hair) plus "stoma" (mouth), and refers to the surface hairs on the molar of the mandible.

\section{SUM MARY}

Haptolana trichostoma, described from 2 specimens collected in a cave in Camagüey Province, Cuba, is distinguished especially by the expanded peduncle of antenna 1, the posteriorly directed mandibular palp, and in having all 7 pereopods prehensile. This is the second recorded occurrence of a troglobitic cirolanid in Cuba and the eighth species reported from the Western Hemisphere.

\section{RÉ SUMÉ}

Haptolana trichostoma, décrit içi d'après deux exemplaires capturés dans une grotte de la province de Camagüey à Cuba, se caractérise principalement par les antennes 1 dont le pédoncule est dilaté, par 1 le palpe mandibulaire dirigé vers l'arrière et par les sept péréopodes tous préhensiles.

C'est la seconde fois qu'un Cirolanide troglobie est cité de Cuba et la huitième espèce signalée de l'hémisphère occidental.

\section{REFERENCES}

Bowman, Thomas E. - 1964: Antrolana lira, a new genus and species of troglobitic cirolanid isopod from Madison Cave, Virginia. Intern. J. Speleology $1(1+2)$ : 229-236, pls. 50-57.

Rioja, Enrique - 1957: Estudios carcinologicos. XXXV. Datos sobre algunos isópodos cavernícolos de la isla de Cuba. An. Inst. Biol., México 27 (2): 437-462. 


\section{EXPLANATION OF PLATES 24 (1) - 27 (4) PLATE 24 (1)}

Figs. 1-9: Haptolana trichostoma, new species. 1. Dorsal view; 2. Lateral view; 3 . Head, ventral; 4 . Head, lateral, left antenna 1 and 2 removed; 5. Right side of pleon, ventral; 6. Pereonite 7, pleon, and telson, dorsal; 7. Posterior margin of telson, dorsal; 8. Right uropod, dorsal; 9. Apex of uropodal endopod, dorsal.

\section{PLATE 25 (2)}

Figs. 10-19: Haptolana trichostoma, new species. 10. Antenna 1; 11. Distal end of peduncle, antenna 1; 12. Detail of flagellar segments, antenna 1; 13. Distal flagellar segment, antenna $1 ; 14$. Antenna $2 ; 15$. Detail of flagellar segments, antenna $2 ; 16$. Distal flagellar segment, antenna 2; 17. Maxilla 1; 18. Maxilla 2; 19. Maxilliped.

\section{PLATE 26 (3)}

Figs. 20-27. Haptolana trichostoma, new species. 20. Incisor, right mandible; 21. Incisor, left mandible; 22. Right mandible; 23. Pereopod 1; 24. Pereopod 4; 25. Propodus and dactyl, pereopod 4; 26. Distal end of dactyl, pereopod 4; 27. Pereopod 5.

\section{PLATE 27 (4)}

Figs. 28-33. Haptolana trichostoma, new species. 28. Pleopod 1; 29. Pleopod 2, male; 30. Apex of stylet of male pleopod 2;31. Pleopod 3; 32. Pleopod $4 ; 33$. Pleopod 5 . 


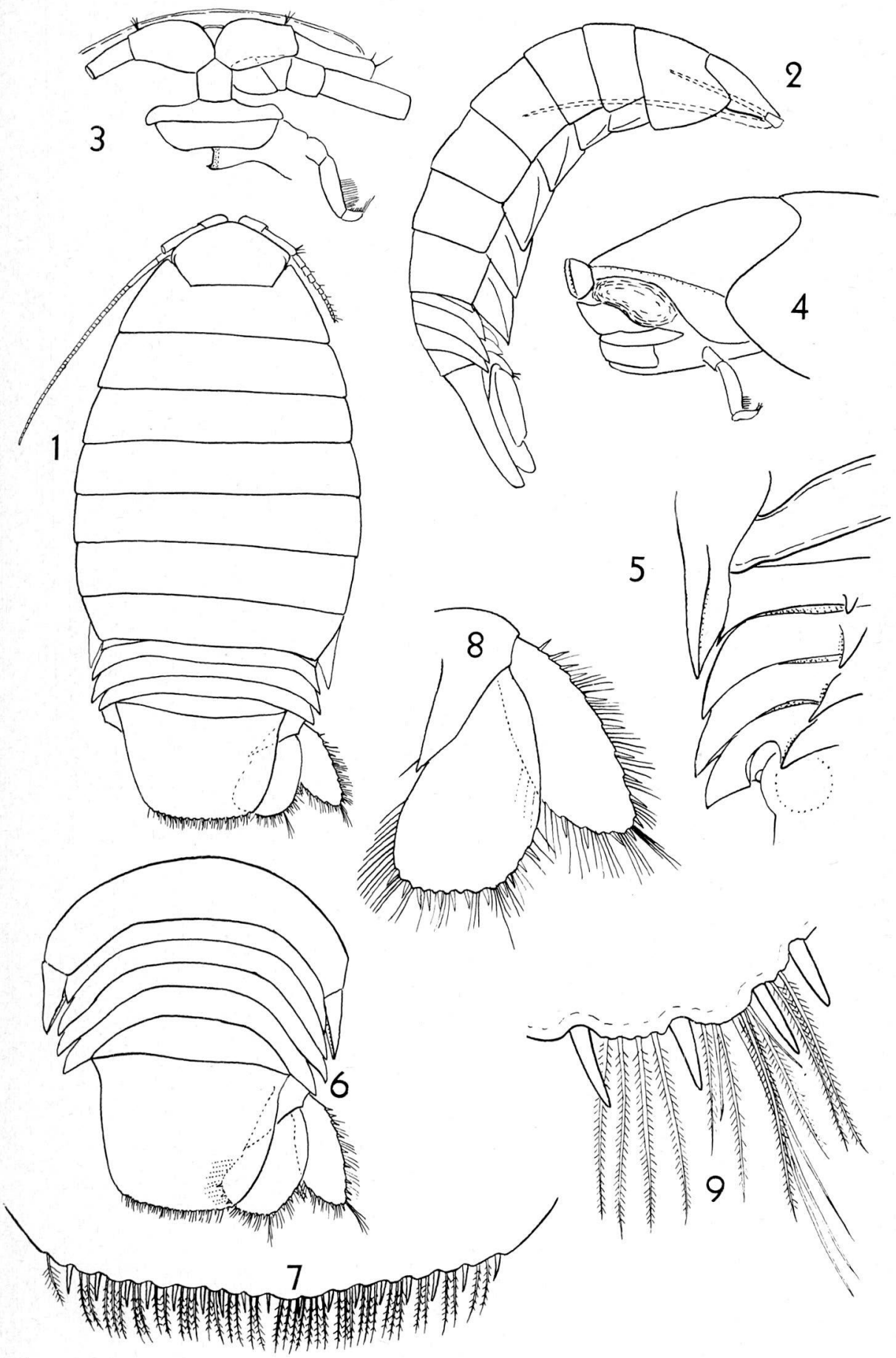



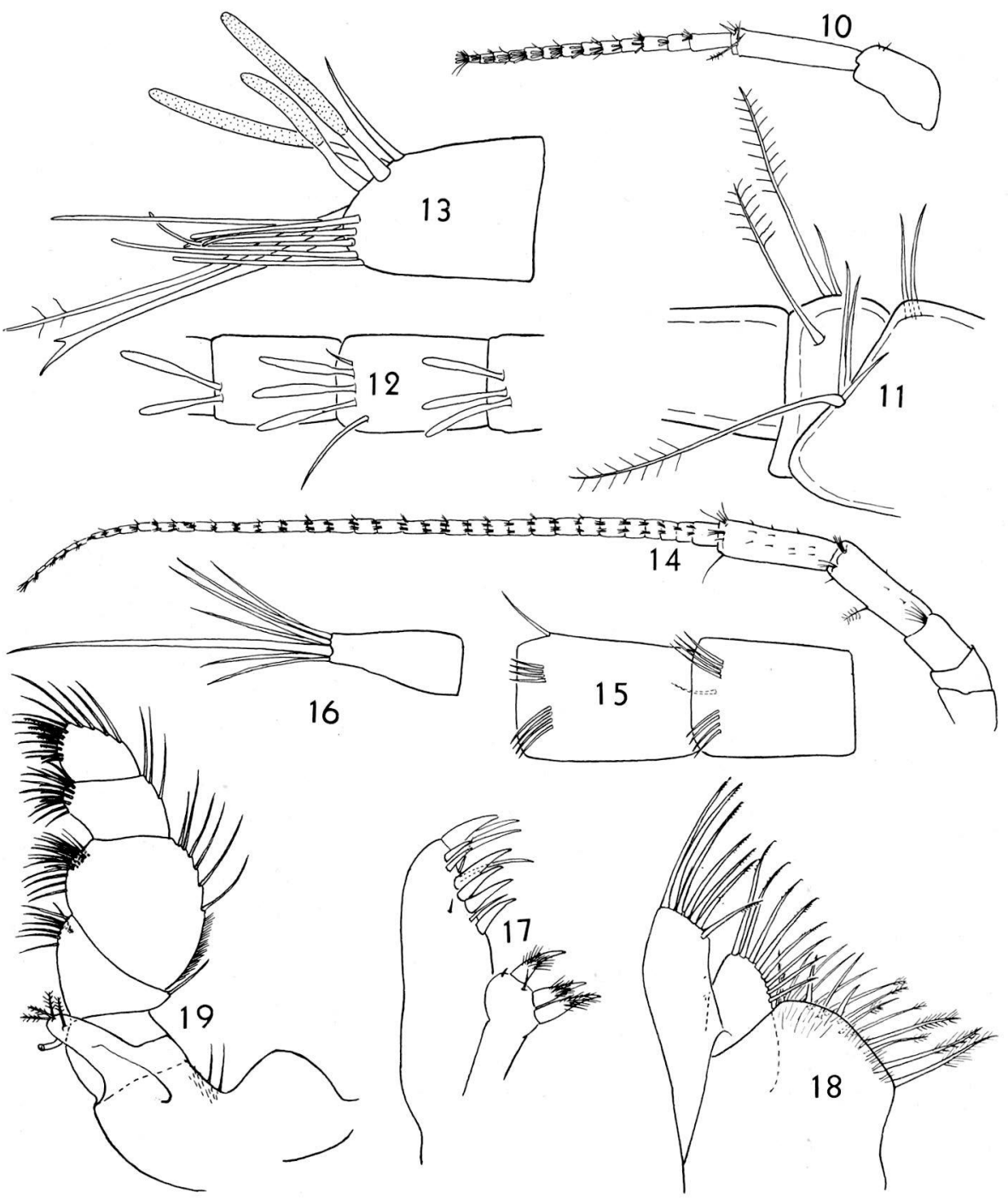


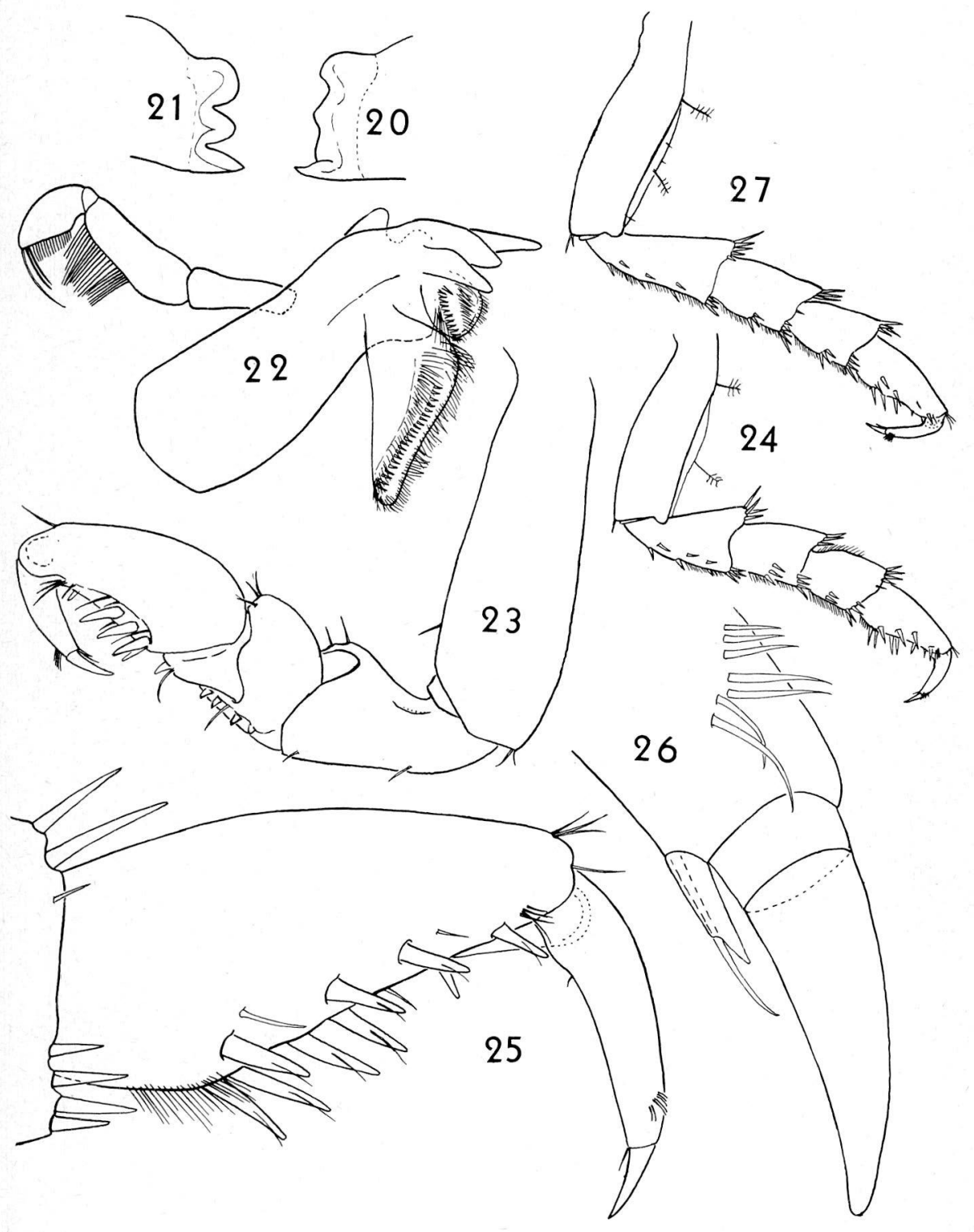




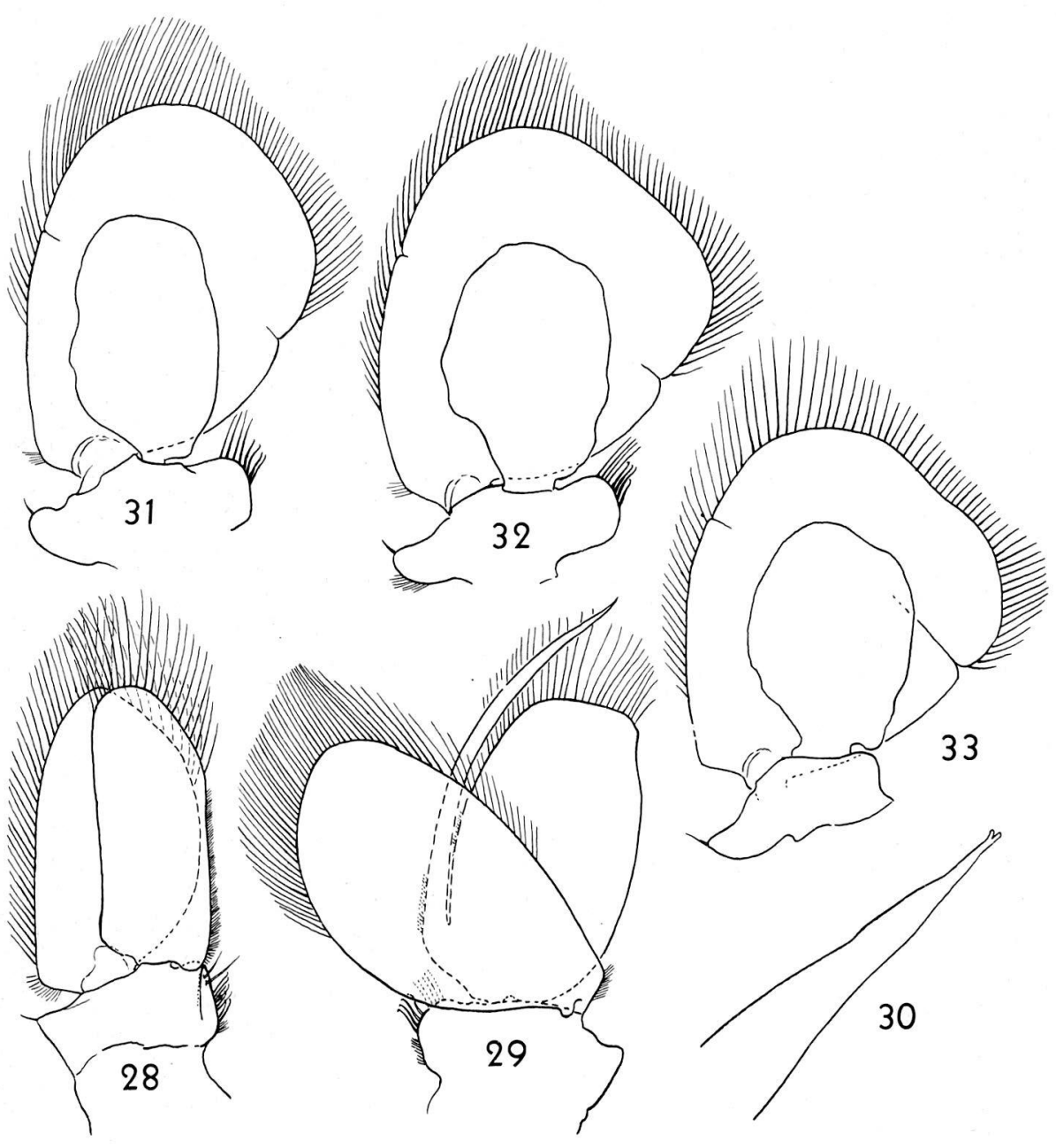

